\title{
PERANCANGAN AR DAN VR BERBASIS ANDROID UNTUK MEDIA PROMOSI PENGEMBANG PERUMAHAN PT. GRIYA PANTURA MANDIRI KENDAL
}

\author{
Yuli Fitrianto', Muhammad Khoiril Anaam² \\ ${ }^{1}$ Teknik Informatika - Universitas STEKOM, yuli f@stekom.ac.id \\ ${ }^{2}$ Desain Grafis - Universitas STEKOM, muhammadkhoirilanaam@gmail.com \\ Jl. Majapahit 605, Semarang, telp/fax : 024-6717201-02
}

\section{ARTICLE INFO}

Article history:

Received 30 Mei 2020

Received in revised form 2 Juni 2020

Accepted 10 Juli 2020

Available online 17 Juli 2020

\begin{abstract}
Augmented Reality (AR) and Virtual Reality (VR) which are one of the top ten strategic technology trends for 2019 and continue to be developed massively in this 2020, have been widely applied in various mobile applications by many companies in this industrial revolution era 4.0. AR can be applied to help the promotion for housing developers where users can see the 3-dimensional shape of the types of houses offered, while VR allows users to explore each part of the house in a virtual 3D. Pre-existing brochures are used as markers for this application to work, so that AR and VR applications can be a complement to promotional media. The design method used in this paper is Research and Development (RnD). Salespeople can offer types of houses to prospective customers without having to print multiple brochures, but with just one brochure and one android smartphone to present, so the promotion costs are more efficient.
\end{abstract}

Keywords: AR, VR, house.

\section{Pendahuluan}

Era revolusi industri 4.0 di tahun 2020 ini mendorong semua kegiatan berbasis digital, dimana muncul platform-platform digital yang mendukung perekonomian, salah satunya di bidang promosi dan pemasaran.

Perkembangan teknologi saat ini tidak berhenti di digitalisasi, tetapi mulai merambah ke penerapan artificial intelligence (AI), salah satunya adalah penerapan teknologi immersive yang meliputi augmented reality (AR) dan virtual reality (VR), yang masuk dalam 10 besar teknologi strategis di tahun 2019 [1].

Penerapan AR sebagai alat bantu promosi sudah dilakukan oleh banyak perusahaan. Contohnya yaitu perusahaan mobil yang ingin menunjukkan produk mobil mereka kepada calon pembeli dengan menggunakan AR berbentuk mobil yang didesain mirip dengan produk mobil mereka, sehingga tercipata efisiensi dimana para sales tidak perlu membawa contoh produk yang berukuran besar, tetapi cukup dengan membawa satu contoh brosur yang kemudian dilakukan scan untuk menampilkan fitur AR dalam sebuah smartphone, tetapi tentu saja teknologi ini tidak serta merta menggantikan fungsi brosur sebagai media promosi melainkan sebagai pelengkap saja, bagi calon pembeli yang tertarik dan paham akan teknologi.

Penelitian-penelitian terkait AR untuk media promosi perumahan contohnya adalah: 1. Penerapan AR untuk mendukung media promosi Perumahan Patraland Place di kota Malang, dengan menambahkan pola marker pada brosur [2], 2. AR diterapkan sebagai media promosi penjualan perumahan dengan menggunakan marker hitam-putih [3] 
p-ISSN : 1979-0414 e-ISSN : 2621-6256

Penerapan VR tidak jauh beda dengan AR dalam hal pelengkap media promosi, hanya saja melalui VR calon konsumen dapat memasuki lingkungan virtual baik dalam bentuk foto realistik, model 3 dimensi ataupun gabungan dari keduanya, contohnya adalah jalan-jalan virtual ke suatu tempat wisata atau bangunan tertentu yang ditawarkan, sebagai bentuk uji coba virtual sebelum mereka datang ke tempat aslinya.

Penelitian-penelitian terkait VR untuk media promosi perumahan contohnya adalah: 1. Perancangan VR yang menampilkan video 360 derajat, dimana video tersebut menampilkan bangunan rumah secara 3D untuk media promosi Perumahan Zarindah [4], 2. Perancangan 3D VR untuk promosi perumahan berbasis web online [5].

PT. Griya Pantura Mandiri, PT. Griya Pantura Mandiri merupakan sebuah developer perumahan di daerah Kendal yang berdiri sejak tahun 2015 dipimpin oleh Agus Solikhin dengan tujuan memberikan hunian yang nyaman dengan harga yang terjangkau. Sudah beberapa perumahan yang sudah dibangun oleh PT. Griya Pantura Mandiri, Kendal.

Media yang digunakan untuk kegiatan promosi selama ini yaitu brosur. Brosur sendiri memiliki ciri yaitu tujuannya menginformasikan produk kepada masyarakat luas, dibuat semenarik mungkin agar menarik perhatian publik, desainnya menarik dan isinya jelas.

Penelitian ini menawarkan solusi yaitu berupa aplikasi berbasis android yang menerapkan teknologi AR dengan brosur sebagai marker-nya dan VR yang mengijinkan pengguna untuk menelusuri setiap bagian rumah secara virtual 3D, dengan tujuan untuk memperkaya visualisasi dari tipe-tipe rumah yang ditawarkan untuk menunjang promosi dari perusahaan pengembang perumahan. Novelty atau kebaruan dari penelitian ini dibandingkan dengan penelitian-penelitian sebelumnya adalah menggabungkan teknologi AR dan VR dalam satu aplikasi berbasis android, dan marker yang digunakan untuk AR adalah jenis multiple-marker yang berwarna.

\section{Metode Penelitian}

Metode yang digunakan dalam penelitian ini yaitu metode Research and Development (RnD). Menurut Sugiyono (2009) dalam Haryati (2012) berpendapat bahwa, metode penelitian dan pengembangan adalah metode penilitian yang digunakan untuk menghasilkan produk tertentu, dan menguji keefektifan produk tersebut [6].

Menurut Borg \& Gall (1989) dalam Oka (2017), RnD telah menjadi ujung tombak dari suatu industri dalam menghasilkan produk-produk baru yang dibutuhkan oleh pasar. Hampir 4\% biaya yang digunakan untuk penelitian dan pengembangan, bahkan untuk industri farmasi dan komputer lebih dari 4\% [7].

Menurut Borg dan Gall (1989) ada langkah pelaksanaan strategi RnD yang dilakukan untuk menghasilkan produk tertentu untuk menguji keefektifan produk yang dimaksud. Adapun langkah-langkah penelitian dan pengembangan adalah seperti pada gambar 1 berikut ini:

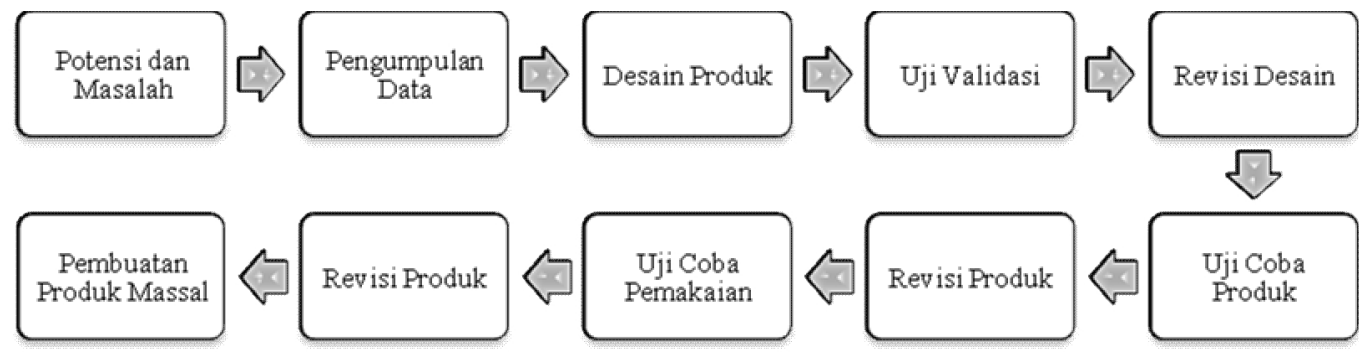

Gambar 1. 10 Langkah Research and Development

Penelitian ini mengambil 6 dari 10 langkah RnD di atas, yaitu hanya sampai ke uji coba produk, berikut ini adalah penjelasan rinci dari keenam langkah tersebut:

\subsection{Potensi dan Masalah}

Potensi yang ada yang mendukung perusahaan dalam mengembangkan proyek perumahan adalah Kabupaten Kendal memiliki jumlah penduduk sebesar 978.672 orang. Batas usia kerja yang berlaku di Indonesia adalah berumur 15-64 tahun. Kabupaten Kendal memiliki penduduk yang tergolong tenaga kerja 
umur 15-64 tahun sebesar 700.045 orang. Dengan jumlah penduduk yang sudah bekerja tersebut pasti dibutuhkan rumah hunian sebagai tempat tinggal. Potensi yang lain adalah di tahun 2020 ini adalah jumlah kepemilikan smartphone semakin tinggi.

Masalah yang dialami perusahaan adalah kurang efektifnya media promosi yang selama ini digunakan yaitu media promosi berbentuk cetak yaitu brosur, dengan beberapa kelemahannya media brosur yang hanya berupa lembaran kertas adalah informasi visual yang diberikan kurang detail karena visualisasinya terbatas pada gambar atau foto statis, membutuhkan biaya besar untuk mencetak dalam jumlah banyak serta mudah hilang dan rusak. Kelemahan lainnya adalah brosur dianggap tidak berguna sehingga dibuang ke sampah dan dianggap mengganggu privasi pada saat proses penyebarannya [8].

\subsection{Pengumpulan Data}

Data awal yang dibutuhkan adalah data tingkat efektifitas brosur yang selama ini digunakan oleh PT. Griya Pantura Mandiri, yang diperoleh melalui kuesioner dengan 10 pertanyaan dengan mengambil sampel responden masyarakat Kendal secara acak berjumlah 20 orang. Kepemilikan smartphone android dari 20 responden yaitu 100\%. Terdapat beberapa aspek yang diperhitungkan untuk menilai tingkat efektifitas brosur yaitu sebagai alat informasi, promosi, dan petunjuk karakter. Pertanyaan tingkat efektifitas brosur, dengan pertanyaan khusus nomor 8 dan 10 dimana jawaban ya $(Y)=$ bernilai 0 , sedangkan tidak $(\mathrm{T})=1$ seperti ditampilkan pada tabel 1 berikut ini:

Tabel 1. Kuesioner Tingkat Efektifitas Brosur

\begin{tabular}{|c|c|c|c|}
\hline No & Pertanyaan & $\mathbf{Y}$ & $\mathbf{T}$ \\
\hline 1. & $\begin{array}{l}\text { Apakah anda tahu di daerah Sarirejo, Kaliwungu ada perumahan } \\
\text { baru yang ditawarkan? }\end{array}$ & & \\
\hline 2. & $\begin{array}{l}\text { Apakah anda tahu di daerah Kutoharjo, Kaliwungu ada perumahan } \\
\text { baru yang ditawarkan? }\end{array}$ & & \\
\hline 3. & $\begin{array}{l}\text { Apakah anda tahu di daerah Krajankulon, Kaliwungu ada perumahan } \\
\text { baru yang ditawarkan? }\end{array}$ & & \\
\hline 4. & $\begin{array}{l}\text { Setelah melihat brosur ini, apakah informasi yang diberikan sudah } \\
\text { lengkap? }\end{array}$ & & \\
\hline 5. & $\begin{array}{l}\text { Apakah anda bisa membayangkan tipe } 30^{+} \text {secara detail sesuai } \\
\text { brosur? }\end{array}$ & & \\
\hline 6. & $\begin{array}{l}\text { Apakah anda bisa membayangkan tipe } 36 \text { secara detail sesuai } \\
\text { brosur? }\end{array}$ & & \\
\hline 7. & $\begin{array}{l}\text { Apakah anda bisa membayangkan tipe } 36^{+} \text {secara detail sesuai } \\
\text { brosur? }\end{array}$ & & \\
\hline 8. & $\begin{array}{l}\text { Seumpama ada visual 3D untuk rumah tersebut meningkatkan } \\
\text { informasi yang anda dapat lebih detail? }\end{array}$ & & \\
\hline 9. & Berdasarkan brosur ini apakah anda tertarik untuk membeli? & & \\
\hline 10. & $\begin{array}{l}\text { Seumpama brosur ini menampilkan visual 3D rumah apakah anda } \\
\text { lebih tertarik membeli? }\end{array}$ & & \\
\hline
\end{tabular}

Kuesioner di atas dilakukan dengan responden sejumlah 20 orang. Hasil kuesionernya dapat dilihat pada tabel 2 sebagai berikut:

Tabel 2. Data Responden Tingkat Efektifitas Brosur

\begin{tabular}{|c|c|c|c|}
\hline \multirow{2}{*}{ No } & \multirow{2}{*}{ Responden } & \multicolumn{2}{|c|}{ Jawaban } \\
\cline { 3 - 4 } & & Ya & Tidak \\
\hline 1. & R1 & 3 & 7 \\
\hline 2. & R2 & 3 & 7 \\
\hline 3. & R3 & 1 & 9 \\
\hline 4. & R4 & 6 & 4 \\
\hline 5. & R5 & 2 & 8 \\
\hline
\end{tabular}

JURNAL ILMIAH KOMPUTER GRAFIS Vol. 13, No. 1, Juli 2020: 16 - 27 
p-ISSN : 1979-0414 e-ISSN : 2621-6256

\begin{tabular}{|c|c|c|c|}
\hline 6. & R6 & 1 & 9 \\
\hline 7. & R7 & 2 & 8 \\
\hline 8. & R8 & 2 & 8 \\
\hline 9. & R9 & 2 & 8 \\
\hline 10. & R10 & 0 & 10 \\
\hline 11. & R11 & 2 & 8 \\
\hline 12. & R12 & 2 & 8 \\
\hline 13. & R13 & 5 & 5 \\
\hline 14. & R14 & 3 & 7 \\
\hline 15. & R15 & 4 & 6 \\
\hline 16. & R16 & 3 & 7 \\
\hline 17. & R17 & 6 & 4 \\
\hline 18. & R18 & 4 & 6 \\
\hline 19. & R19 & 1 & 9 \\
\hline 20. & R20 & 4 & 6 \\
\hline \multicolumn{2}{|c|}{ Jumlah } & 56 & 144 \\
\hline \multicolumn{2}{|c|}{ Rata-rata } & 5,6 & 14,4 \\
\hline
\end{tabular}

Berikut ini perhitungan data responden di atas:

Perhitungan jawaban "Tidak":

$$
\begin{aligned}
& T=\frac{\text { Rata }- \text { rata jawaban "Tidak" }}{\text { Jumlah responden }} \times 100 \% \\
& T=\frac{14,4}{20 \times 100} \%=72 \%
\end{aligned}
$$

Berdasarkan perhitungan di atas dapat disimpulkan bahwa $72 \%$ responden kurang paham mengenai informasi dan visualisasi pada brosur, oleh karena itu dibutuhkan adanya visual 3D pada brosur, agar informasi yang diberikan lebih detail, dan dari aspek promosi menjadi lebih menarik karena adanya pemanfaatan 3D AR dan VR tentang bentuk rumah dan ruangan yang terdapat di dalamnya. Melihat dari poin no 9 , ketertarikan membeli berdasarkan brosur yang ada dari 20 responden adalah hanya sebesar $25 \%$.

\subsection{Desain Produk}

2.3a. Desain User Interface (UI)
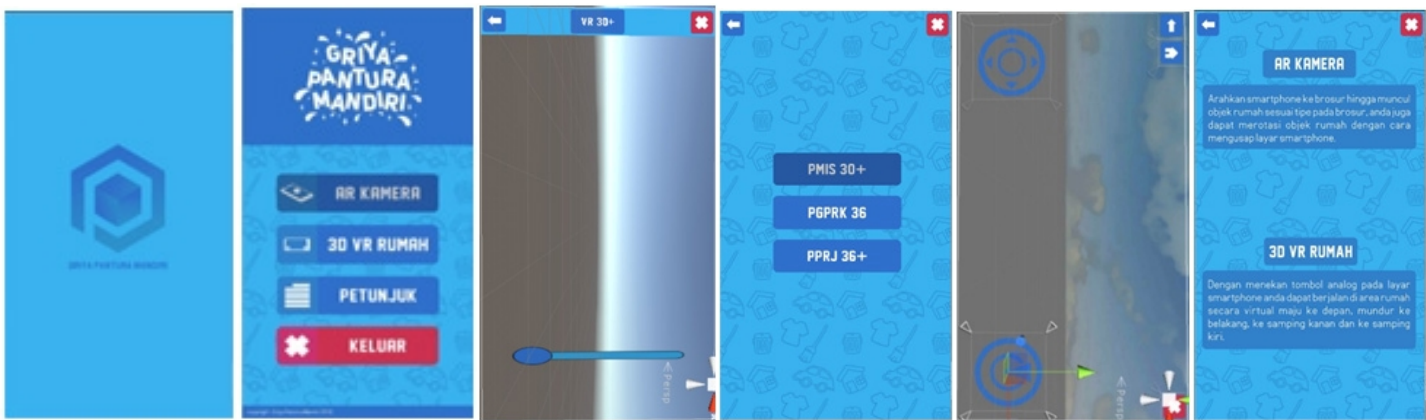

Gambar 2. Desain User Interface

\section{3b. Desain Model Rumah 3D}

Desain model rumah dibuat dengan menggunakan software 3 dimensi untuk komputer desktop atau laptop, dalam hal ini digunakan software Google Sketchup, dimana proses pembuatannya seperti pada gambar 2 di bawah ini: 


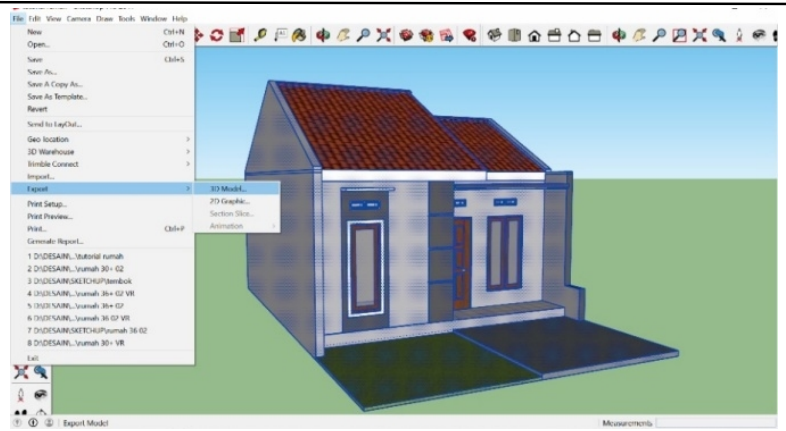

Gambar 3. Desain Model Rumah dalam 3 Dimensi

\section{3c. Desain AR dengan Unity3D dan Vuforia}

Brosur yang selama ini digunakan oleh pihak pengembang, dimanfaatkan sebagai marker yang berfungsi sebagai penanda untuk memicu munculnya objek model rumah 3D secara real-time melalui kamera smartphone. Gambar 4 berikut ini adalah 3 brosur berdasarkan tipe rumah yang ditawarkan, yang difungsikan sebagai marker untuk AR:
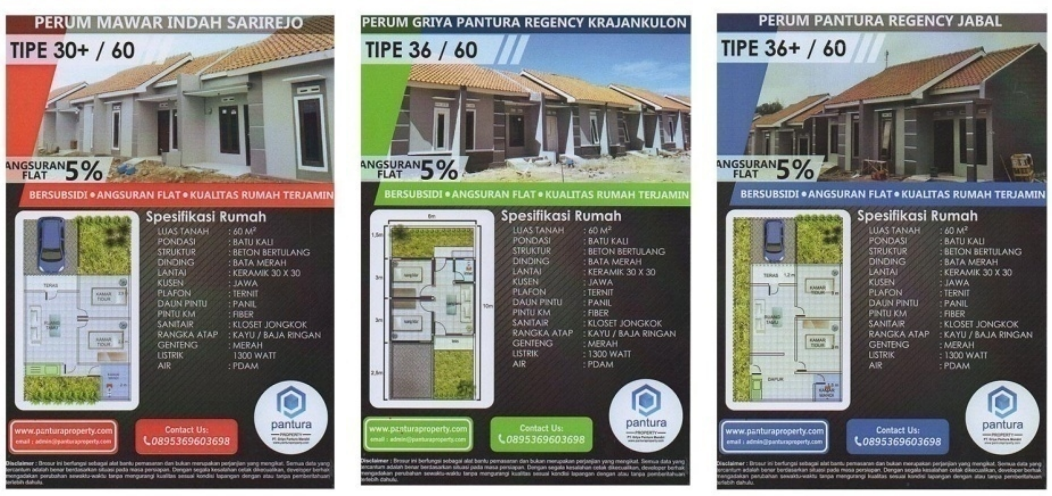

Gambar 4. Brosur sebagai Marker

Gambar 5 berikut ini adalah posisi model rumah 3D terhadap marker berdasarkan tipe rumahnya:

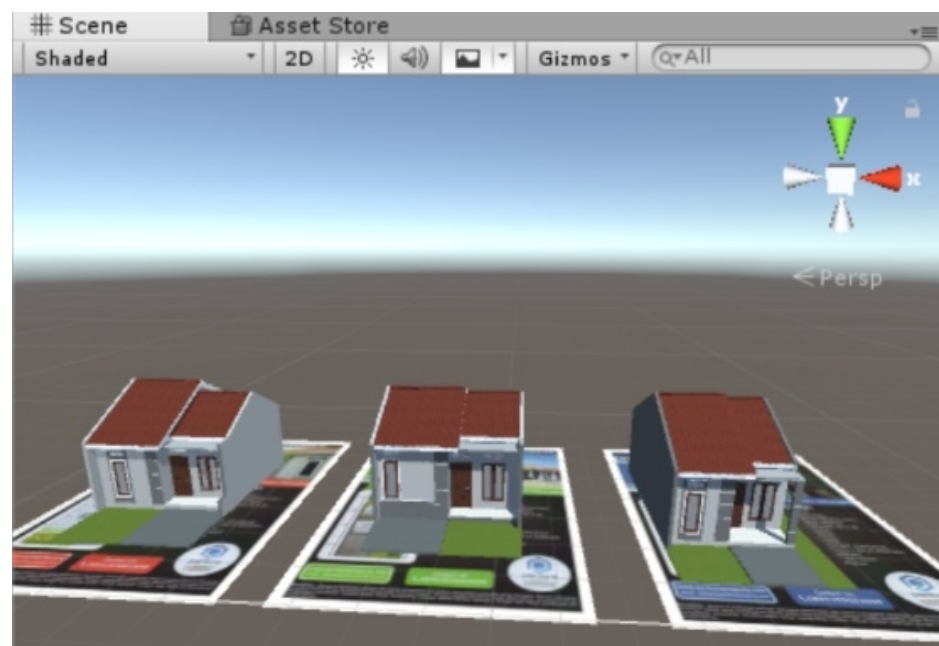

Gambar 5. Posisi Model Rumah 3D terhadap Marker

JURNAL ILMIAH KOMPUTER GRAFIS Vol. 13, No. 1, Juli 2020 : $16-27$ 
p-ISSN : 1979-0414 e-ISSN : 2621-6256

Gambar 6 berikut ini adalah tampilan ketika AR Camera mulai difungsikan:

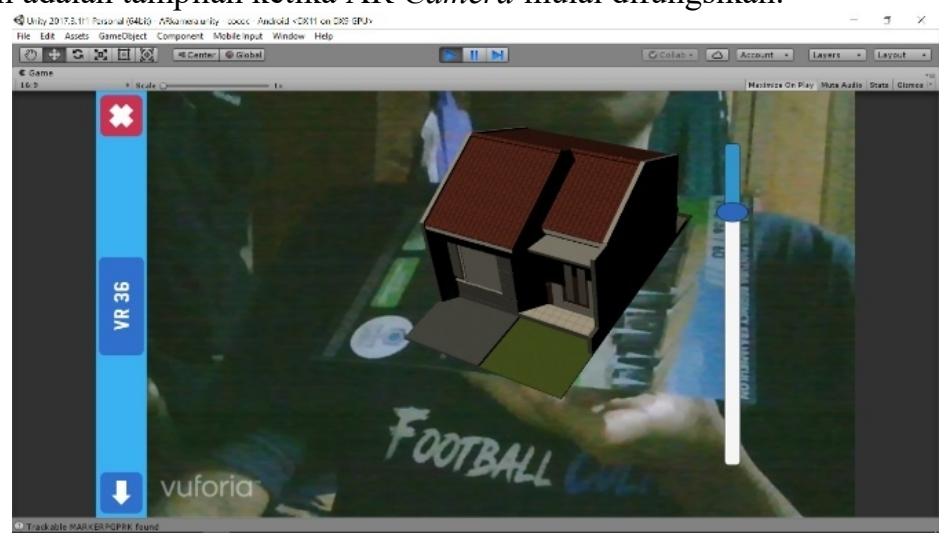

Gambar 6. Aktivasi Kamera AR terhadap Marker

\section{3d. Desain VR dengan Unity3D}

Gambar 7 berikut ini adalah tampilan dari VR yang menunjukkan posisi awal dari user sebelum memulai untuk jalan-jalan menelusuri seluruh bagian rumah:

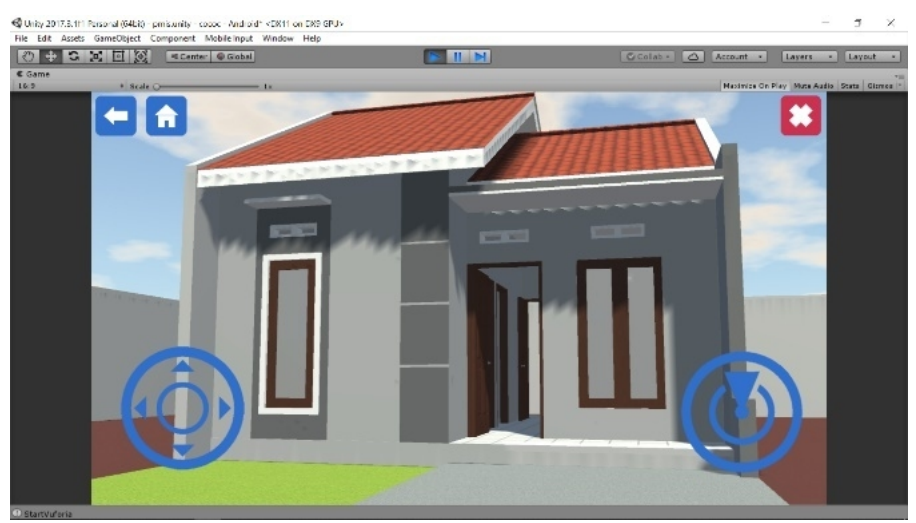

Gambar 7. Tampilan dan Posisi Awal User pada Fitur VR

Tampilan di atas memperlihatkan bahwa user dapat menelusuri setiap bagian dari model rumah 3D per-tipe yang ditawarkan oleh pihak pengembang melalui sudut pandang orang pertama, dengan beberapa tombol operasi, yaitu:

1. tombol back berbentuk panah ke kiri dan berwarna biru untuk kembali ke halaman sebelumnya, di sebelah kiri atas,

2. tombol home berbentuk icon rumah ke kiri dan berwarna biru untuk kembali ke halaman awal di sebelah tombol back di kiri atas,

3. tombol kontrol gerak maju-mudur dan geser kiri-kanan berbentuk lingkaran dengan 4 penjuru anak panah dan berwarna biru di sebelah kiri bawah,

4. tombol kontrol untuk melihat sekeliling secara 360 derajat berbentuk lingkaran seperti radar dan berwarna biru di sebelah kanan bawah, dan

5. tombol close berbentuk silang dan berwarna merah di sebelah kanan atas untuk menutup aplikasi.

\subsection{Uji Validasi}

Penentuan kelayakan penerapan AR dan VR pada brosur sebagai alat bantu media promosi PT. Griya Pantura Mandiri Kendal diukur berdasarkan penilaian validasi dari para ahli yaitu ahli media dan ahli materi, sedangkan untuk user masuk pada tahap uji coba produk.

Saran yang terdapat dalam instrumen digunakan sebagai bahan pertimbangan untuk perbaikan alat bantu media promosi lebih lanjut. Berikut ini adalah hasil pengujian dari masing-masing validator: 


\section{4a. Validasi Ahli Media}

Ahli media adalah pihak yang mempunyai kompetensi atau ahli di bidang media, dalam hal ini adalah ahli di bidang tampilan UI, AR dan VR. Hasil validasi ahli media dapat dilihat pada tabel 3 berikut ini:

Tabel 3. Angket Validasi Ahli Media

\begin{tabular}{|c|l|c|c|c|c|}
\hline No Indikator & \multicolumn{1}{|c|}{1} & 2 & 3 & 4 \\
\hline 1 & Layout/tata letak background, teks, dan tombol & & & & $\sqrt{ }$ \\
\hline 2 & Fungsi tombol berjalan dengan baik & & & & $\sqrt{ }$ \\
\hline 3 & Kejelasan sound narasi & & & $\sqrt{ }$ & \\
\hline 4 & Keterbacaan teks & & & & $\sqrt{ }$ \\
\hline 5 & Pilihan warna menarik & & & $\sqrt{ }$ \\
\hline 6 & Kualitas gambar dan dukungan resolusi & & & & $\sqrt{ }$ \\
\hline 7 & Pembacaan marker ke model 3D berjalan baik & & & $\sqrt{ }$ \\
\hline 8 & Rotasi model 3D berjalan baik & & & \\
\hline 9 & $\begin{array}{l}\text { Sudut pandang 3D (x,y,z) dengan kesesuaian gerak } \\
\text { (jalan) player first person controller (FPC) }\end{array}$ & & & & $\sqrt{ }$ \\
\hline 10 & Estetika total aplikasi JUMLAH SKOR & & & 6 & 32 \\
\hline & \multicolumn{1}{|c|}{ JUMLAH SKOR TOTAL } & & \\
\hline
\end{tabular}

Hasil validasi ahli media melalui angket di atas, perhitungan nilai yang diperoleh adalah sebagai berikut:

Kurang ( 1 x 0$) \quad$ : 0

Cukup $\quad(2 \times 0): 0$

Baik $\quad(3 \times 2): 6$

Sangat baik $\quad(4 \times 8): 32+$

38

nilai validasi $: \mu=\frac{\sum x}{\eta}=\frac{28}{10}=\mathbf{3}, \mathbf{8}$

Berdasarkan perhitungan di atas, diketahui bahwa hasil validasi dari ahli media adalah 3,8. Kriteria ini berada diantara 3,26 - 4,00 yaitu tergolong dalam kategori sangat valid. Sehingga aplikasi ini dapat dikatakan layak untuk digunakan.

$\frac{3,8}{4} \%=95 \%$

Validasi ahli media diperoleh hasil dalam persen sebesar 95\%.

2.4b. Validasi Ahli Materi

Ahli materi adalah pihak perusahaan pengembang perumahan yang menguasai detail produk yang ditawarkan. Hasil validasi ahli materi dapat dilihat pada tabel 4 berikut ini:

Tabel 4. Angket Validasi Ahli Materi

\begin{tabular}{|c|c|c|c|c|c|}
\hline No & Indikator & 1 & 2 & 3 & 4 \\
\hline 1 & Bentuk fisik 3D tipe 30+ secara umum mendekati bentuk aslinya & & & & $\sqrt{ }$ \\
\hline 2 & Bentuk fisik 3D tipe 36 secara umum mendekati bentuk aslinya & & & & $\sqrt{ }$ \\
\hline 3 & Bentuk fisik 3D tipe $36+$ secara umum mendekati bentuk aslinya & & & & $\sqrt{ }$ \\
\hline 4 & Skala 3D model secara horisontal dan vertikal mendekati aslinya & & & & $\sqrt{ }$ \\
\hline 5 & 3D model bangunan terletak sesuai denah aslinya & & & & $\sqrt{ }$ \\
\hline 6 & Warna/material 3D model mendekati bentuk aslinya & & & & $\sqrt{ }$ \\
\hline 7 & Sound narasi tipe $30+$ berisi informasi sesuai aslinya & & & & $\sqrt{ }$ \\
\hline 8 & Sound narasi tipe 36 berisi informasi sesuai aslinya & & & & $\sqrt{ }$ \\
\hline 9 & Sound narasi tipe $36+$ berisi informasi sesuai aslinya & & & & $\sqrt{ }$ \\
\hline
\end{tabular}

JURNAL ILMIAH KOMPUTER GRAFIS Vol. 13, No. 1, Juli 2020 : $16-27$ 
p-ISSN : 1979-0414 e-ISSN : 2621-6256

\begin{tabular}{|c|c|c|c|c|}
\hline 10 & Hasil produk dapat menjadi alat bantu visualisasi & & & $\sqrt{ }$ \\
\hline & JUMLAH SKOR & & 40 \\
\hline & JUMLAH SKOR TOTAL & \multicolumn{2}{|c|}{40} \\
\hline
\end{tabular}

Hasil validasi ahli materi melalui angket di atas, maka perhitungan nilai yang diperoleh adalah sebagai berikut:

Kurang $\left(\begin{array}{lll}1 & \mathrm{x} & 0\end{array}\right)$ : 0

Cukup $\quad(2 \times 0): 0$

Baik $\quad(3 \times 0) \quad: 0$

Sangat baik $\quad(4 \times 10): 40+$

nilai validasi: $\mu=\frac{\Sigma x}{n}=\frac{40}{1 n}=4$

Berdasarkan perhitungan di atas, diketahui bahwa hasil validasi dari ahli materi adalah 4. Kriteria ini berada diantara 3,26 - 4,00 yaitu tergolong dalam kategori sangat valid. Sehingga aplikasi ini dapat dikatakan layak untuk digunakan.

$\frac{4}{4} \%=100 \%$

Hasil validasi dari ahli materi diperoleh hasil nilai dalam persen sebesar 100\%.

\subsection{Revisi Desain}

Revisi pada desain pada aplikasi ini hanya sedikit yaitu pada narasi suara yang kurang begitu terdengar jelas ketika menjelaskan detail rumah, sehingga diperlukan untuk melakukan take ulang perekamannya.

\subsection{Uji Coba Produk}

Langkah terakhir yang diambil dalam metode $\mathrm{RnD}$ yaitu uji coba produk yang dilakukan terhadap 20 user dengan orang sama ketika memperoleh data awal pada tabel 1.

Hasil uji coba produk oleh user dapat dilihat pada tabel 5 berikut ini:

Tabel 5. Uji CobaUser

\begin{tabular}{|c|c|c|c|c|c|}
\hline No & Indikator & 1 & 2 & 3 & 4 \\
\hline 1 & Apakah tampilan awal menarik? & & & & \\
\hline 2 & Apakah mudah dalam pengoperasiannya? & & & & \\
\hline 3 & Apakah fitur-fitur menyenangkan? & & & & \\
\hline 4 & Apakah sound narasi terdengar jelas? & & & & \\
\hline 5 & $\begin{array}{l}\text { Apakah mendapatkan pengalaman baru dengan } \\
\text { teknologi melalui aplikasi ini? }\end{array}$ & & & & \\
\hline 6 & $\begin{array}{l}\text { Apakah informasi dan gambaran nyata tipe rumah } 30+ \\
\text { sudah terbayang jelas? }\end{array}$ & & & & \\
\hline 7 & $\begin{array}{l}\text { Apakah informasi dan gambaran nyata tipe rumah } 36 \\
\text { sudah terbayang jelas? }\end{array}$ & & & & \\
\hline 8 & $\begin{array}{l}\text { Apakah informasi dan gambaran nyata tipe rumah } 36+ \\
\text { sudah terbayang jelas? }\end{array}$ & & & & \\
\hline 9 & Ketertarikan terhadap tipe-tipe rumah yang ditawarkan & & & & \\
\hline \multirow[t]{3}{*}{10} & $\begin{array}{l}\text { Peluang untuk menceritakan produk yang ditawarkan } \\
\text { kepada orang lain }\end{array}$ & & & & \\
\hline & JUMLAH SKOR & & & & \\
\hline & JUMLAH SKOR TOTAL & & & & \\
\hline
\end{tabular}


Berdasarkan data dari 20 responden dengan 10 jumlah pertanyaan, nilai yang diperoleh adalah sebagai berikut:

Tabel 6. Nilai Angket Uji Coba Produk oleh User

\begin{tabular}{|c|c|c|c|c|c|}
\hline \multirow{2}{*}{ Responden } & \multicolumn{4}{|c|}{ Nilai } & \multirow{2}{*}{ Jumlah } \\
\cline { 2 - 5 } & 1 & 2 & 3 & 4 & \\
\hline 1. & 0 & 0 & 15 & 20 & 35 \\
\hline 2. & 0 & 0 & 18 & 16 & 34 \\
\hline 3. & 0 & 0 & 9 & 28 & 37 \\
\hline 4. & 0 & 0 & 15 & 20 & 35 \\
\hline 5. & 0 & 0 & 12 & 24 & 36 \\
\hline 6. & 0 & 0 & 21 & 12 & 33 \\
\hline 7. & 0 & 0 & 21 & 12 & 33 \\
\hline 8. & 0 & 0 & 12 & 24 & 36 \\
\hline 9. & 0 & 0 & 9 & 28 & 37 \\
\hline 10. & 0 & 0 & 9 & 28 & 37 \\
\hline 11. & 0 & 0 & 12 & 24 & 36 \\
\hline 12. & 0 & 0 & 18 & 16 & 34 \\
\hline 13. & 0 & 0 & 9 & 28 & 37 \\
\hline 14. & 0 & 0 & 15 & 20 & 35 \\
\hline 15. & 0 & 0 & 21 & 12 & 33 \\
\hline 16. & 0 & 2 & 9 & 24 & 35 \\
\hline 17. & 0 & 0 & 9 & 28 & 37 \\
\hline 18. & 0 & 0 & 12 & 24 & 36 \\
\hline 19, & 0 & 0 & 18 & 16 & 34 \\
\hline 20. & 0 & 0 & 18 & 16 & 34 \\
\hline & JUMLAH SKOR TOTAL & 704 \\
\hline
\end{tabular}

Dari hasil pengujian melalui angket yang berjumlah 10 pertanyaan, nilai yang diperoleh:

Kurang $(1 \times 0) \quad: 0$

Cukup $\quad(2 \times 1) \quad: 2$

Baik $\quad(3 \times 94) \quad: 282$

Sangat baik $\quad(4 \times 105): \frac{420+}{704}$

nilai uji coba produk : $\mu=\frac{\sum x}{n}=\frac{704}{20}=35,2 \frac{95,2}{10}=3,52$

Berdasarkan perhitungan di atas, diketahui bahwa hasil uji coba produk olehuser adalah 3,52.Kriteria ini berada diantara 3,26 - 4,00 yaitu tergolong dalam kategori sangat valid. Sehingga aplikasi ini dapat dikatakan layak untuk digunakan.

Nilai dalam persen dapat dihitung sebagai berikut:

$$
\frac{3.52}{4} \%=88 \%
$$

\section{Hasil dan Pembahasan}

Seluruh langkah perancangan dengan metode RnD, dari langkah 1 sampai dengan langkah 6 telah selesai dilakukan, sehingga produk akhir telah diperoleh dan dapat dijalankan melalui perangkat smartphone android. Gambar 8 berikut ini adalah tampilan produk akhir keseluruhan scene yang dijalankan melalui smartphone android:

JURNAL ILMIAH KOMPUTER GRAFIS Vol. 13, No. 1, Juli 2020: 16 - 27 


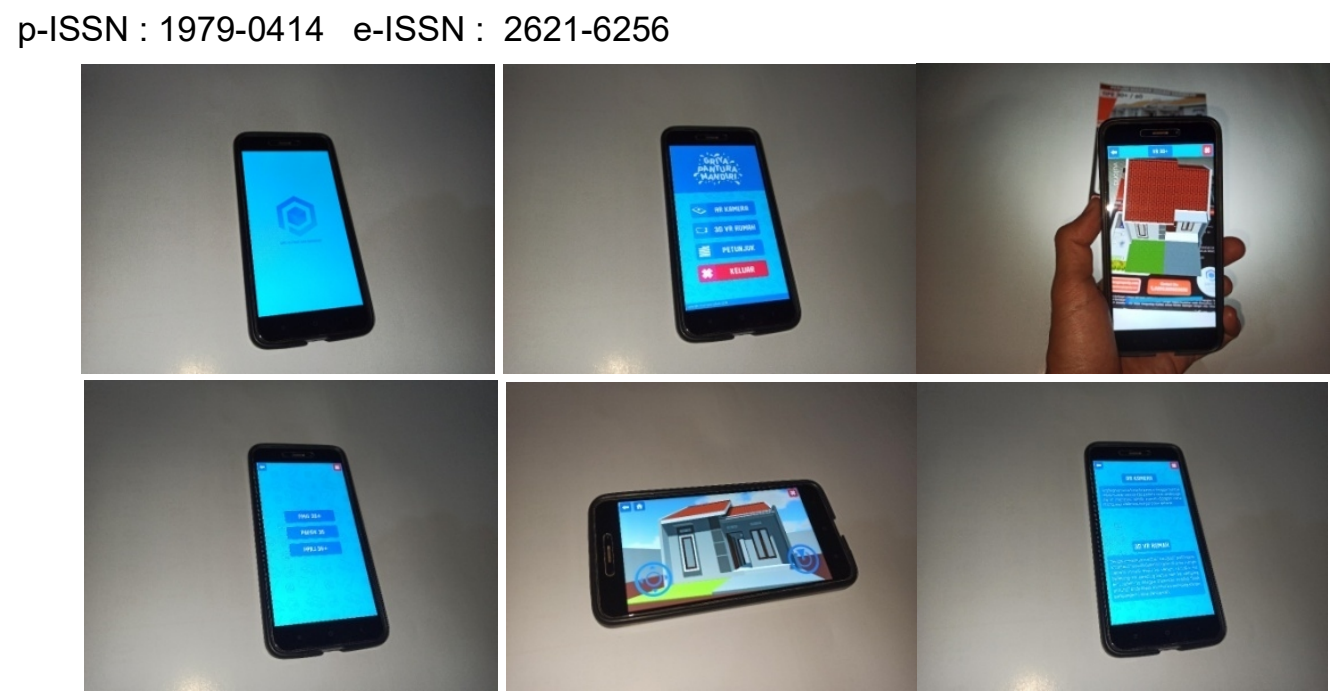

Gambar 8. Tampilan Produk Akhir Keseluruhan Scene pada Smartphone Android

Keterbacaan marker menjadi poin paling penting dalam aplikasi ini, mengingat poin ini memperoleh nilai yang kurang sempurna pada waktu validasi ahli media pada tabel 3 di atas, maka dari itu dilakukan pengujian marker berdasarkan jarak dan sudut untuk mengetahui berapa angka minimal yang direkomendasikan.

Tabel 7 berikut ini adalah pengujian keterbacaan marker berdasarkan jarak dan sudut kamera smartphone terhadap marker:

Tabel 1. Pengujian Marker berdasarkan Jarak dan Sudut

\begin{tabular}{|c|c|c|l|}
\hline No & Jarak & Sudut & \multicolumn{1}{|c|}{ Hasil } \\
\hline 1 & $<5 \mathrm{~cm}$ & $<30^{\circ}$ & Marker tidak terbaca \\
\hline 2 & $<5 \mathrm{~cm}$ & $30^{\circ}$ & Marker tidak terbaca \\
\hline 3 & $<5 \mathrm{~cm}$ & $45^{\circ}$ & Marker tidak terbaca \\
\hline 4 & $<5 \mathrm{~cm}$ & $90^{\circ}$ & Marker tidak terbaca \\
\hline 5 & $10 \mathrm{~cm}$ & $<30^{\circ}$ & Marker tidak terbaca \\
\hline 6 & $10 \mathrm{~cm}$ & $30^{\circ}$ & Marker tidak terbaca \\
\hline 7 & $10 \mathrm{~cm}$ & $45^{\circ}$ & Marker tidak terbaca \\
\hline 8 & $10 \mathrm{~cm}$ & $90^{\circ}$ & Marker tidak terbaca \\
\hline 9 & $20 \mathrm{~cm}$ & $<30^{\circ}$ & Marker tidak terbaca \\
\hline 10 & $20 \mathrm{~cm}$ & $30^{\circ}$ & Marker terbaca \\
\hline 11 & $20 \mathrm{~cm}$ & $45^{\circ}$ & Marker terbaca \\
\hline 12 & $20 \mathrm{~cm}$ & $90^{\circ}$ & Marker terbaca \\
\hline
\end{tabular}

Berdasarkan tabel 1 di atas, maka dapat direkomendasikan sebagai berikut:

1. Dirokemndasikan jarak minimal antara kamera smartphone ke marker adalah $10 \mathrm{~cm}$

2. Dirokemndasikan sudut minimal antara kamera smartphone ke marker adalah 30 derajat

Landasan analisis yang digunakan untuk mengukur efektifitas pada penelitian ini menurut Schemerhon John R. Jr (1986) dalam Sucahyowati (2017) bahwa efektifitas merupakan pencapaian target output yang diukur dengan cara membandingkan output anggaran (OA) dengan output realisasi atau sesungguhnya $(\mathrm{OS})$, jika (OA) > (OS) disebut efektif [9].

Nilai keefektifitasan aplikasi ini didapatkan dari perbandingan penilaian dari user yang sama ketika sebelum (tabel 1) dan sesudah (tabel 6) diterapkannya AR dan VR pada brosur. Berdasarkan data nilai hasil kuesioner sebelum penggunaan produk tingkat keefektifan brosur diperoleh hasil (OS) $28 \%$ dan setelah 
penggunaan produk aplikasi AR dan VR brosur diperoleh hasil (OA) 88\%, jadi keefektifan pada brosur sebagai alat bantu media promosi meningkat $60 \%$ dengan diterapkannya teknologi AR dan VR. Berikut ini adalah diagram perbandingan efektifitas brosur sebelum dan sesudah penggunaan produk dalam persen dapat dilihat pada gambar 9 berikut:

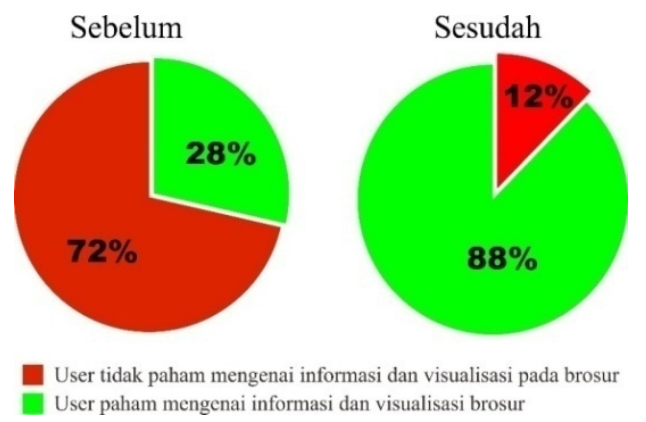

Gambar 9. Grafik Efektifitas Brosur Sebelum dan Sesudah Diterapkan AR dan VR

\section{Simpulan dan Saran}

\section{1. Simpulan}

Berdasarkan hasil penelitian, pengembangan dan pengujian terhadap aplikasi AR dan VR brosur PT. Griya Pantura Mandiri Kendal dapat ditarik kesimpulan sebagai berikut:

1. Masalah yang terjadi pada PT. Griya Pantura Mandiri Kendal yaitu media yang digunakan masih menggunakan brosur, sehingga visualisasi dan informasi yang diberikan kurang detail.

2. Tingkat keefektifan brosur yang terdapat pada PT. Griya Pantura Mandiri, diperoleh melalui kuesioner dengan 10 pertanyaan dengan mengambil sample responden masyarakat Kendal secara acak berjumlah 20 orang dengan hasil $72 \%$ responden kurang paham mengenai informasi dan visualisasi pada brosur.

3. Tingkat kevalidan produk yang dibuat, diperoleh melalui dilakukan validasi oleh ahli media dan ahli materi. Validasi dari ahli media memperoleh hasil 3,8 yang berarti produk sangat valid, validasi ahli materi memperoleh hasil 4,0 yang berarti produk sangat valid untuk digunakan sebagai alat bantu media promosi.

4. Uji coba produk oleh user dengan responden yang sama ketika mencari data awal tingkat keefektifan brosur, berjumlah 20 orang masyarakat sekitar Kendal, memperoleh hasil 3,52 yang berarti produk sangat valid untuk digunakan.

5. Dirokemndasikan jarak minimal antara kamera smartphone ke marker adalah $10 \mathrm{~cm}$ dengan sudut minimal 30 derajat.

6. Tingkat keefektifan pada brosur sebagai alat bantu media promosi meningkat $60 \%$ dengan diterapkannya teknologi AR dan VR.

\section{2. Keterbatasan Hasil Penelitian}

Berdasarkan hasil perancangan dan pengembangan aplikasi AR dan VR pada brosur terdapat kekurangan, antara lain:

1. Aplikasi AR dan VR brosur hanya menampilkan button yang terdapat pada layar smarphone.

2. Aplikasi AR danVR brosur hanya menampilkan mode firstpersoncharacter (FPC).

3. Aplikasi AR dan VR brosur hanya dapat dijalankan melalui smartphone android.

\section{3. Saran}

Berdasarkan hasil penelitian, pembahasan dan kesimpulan di atas maka saran yang diberikan pada penelitian ini adalah:

1. Pengembangan aplikasi AR dan VR ini yang lebih lanjut, dapat diberikan virtualbutton.

2. Pengembangan aplikasiAR dan VR ini yang lebih lanjut, dapat ditambahkan juga mode third person caracter (TPC).

3. Pengembangan aplikasi AR dan VR ini yang lebih lanjut, dapat dijalankan melalui smartphone iOS. 
p-ISSN : 1979-0414 e-ISSN : 2621-6256

\section{Daftar Pustaka}

[1] Cearley D, Burke B. Top 10 Strategic Technology Trends for 2019 Stamford: Gartner, Inc; 2018.

[2] Putri RIP, Irawati DA, Aji DKP. Implementasi Augmented Reality pada Media Promosi Perumahan Patraland Place. Jurnal Informatika Polinema, Volume 1, Edisi 1, November 2014. 2014;: p. 36-40.

[3] Prabowo AZ, Satoto KI, Teguh KM. Perancangan dan Implementasi Augmented Reality sebagai Media Promosi Penjualan Perumahan. Jurnal Teknologi dan Sistem Komputer, Vol.3, No.1, Januari 2015. 2015;: p. 161-170.

[4] Djafar I, Simpen IW, Salmiati. Perancangan Aplikasi Virtual Reality Objek 3D pada Video Promosi Perumahan Zarindah Berbasis Android. In Prosiding Seminar Ilmiah Sistem Informasi dan Teknologi Informasi; 2019; Makasar: STMIK Dipanegara Makassar. p. 161 - 172.

[5] Sri BN, Kurniawan A. Rancang Bangun 3D Virtual Reality untuk Promosi Perumahan Berbasis Web Online. In Seminar Nasional Teknologi Informasi dan Multimedia 2014; 2014; Yogyakarta: STMIK AMIKOM Yogyakarta. p. 25-30.

[6] Haryati S. Research and Development (R\&D) sebagai Salah Satu Model Penelitian dalam Bidang Pendidikan. Jurnal Edutic Vol.37 No.1. 2012;: p. 11-26.

[7] Oka GPA. Model Konseptual Pengembangan Produk Pembelajaran Beserta Teknik Evaluasi Yogyakarta: Deepublish; 2017.

[8] Susanto AB, Wijarnako H. Power Branding: Membangun Merek Unggul dan Organisasi Pendukungnya Bandung: Mizan Pustaka; 2004.

[9] Sucahyowati H. Pengantar Manajemen Malang: Wilis; 2017. 